\title{
PROLEGOMENA DO DYSKUSJI NA TEMAT MODELU SYSTEMU BEZPIECZEŃSTWA NARODOWEGO
}

\author{
Discursive Introduction to the Model for a National Security System
}

\section{Пролегомены для дискуссии на тему модели системы национальной безопасности}

\begin{abstract}
Abstrakt
Cel: Wskazanie zasadniczych cech modelu systemu bezpieczeństwa narodowego decydujących o jego nadrzędności wobec tworzonych na potrzeby lokalne i branżowe.

Wprowadzenie: Bezpieczeństwo państwa, jego rozwój ekonomiczny, polityczny, a tym samym zaangażowanie w kształtowanie bezpiecznego środowiska, a także rosnący poziom zagrożeń dla otwartych społeczeństw - wymuszają konieczność stosowania w praktyce prostych, naukowo uzasadnionych rozwiązań. Założenie takie pozwala bowiem na racjonalne wykorzystywanie posiadanego przez państwo potencjału. Jednym z takich rozwiązań jest budowa systemu bezpieczeństwa narodowego, umożliwiającego równoczesne wykorzystanie elementów obronnych i zarządzania kryzysowego.

Metodologia: W zgodnej ocenie naukowców oraz osób zajmujących się zawodowo problematyką bezpieczeństwa w trosce o jego najwyższy poziom poszukuje się sprawnych i skutecznych metod organizacji systemu bezpieczeństwa narodowego. Poszukiwania tych rozwiązań trwają już od wielu lat. Wykorzystuje się w nich analizy rozważań teoretycznych oraz praktycznych rozwiązań krajowych i zagranicznych.

Wyniki: Bezpieczeństwo państwa charakteryzuje się dynamicznymi zmianami warunków prawnych oraz koncepcyjno-organizacyjnych. Zmiany te powodują konieczność budowy sprawnego systemu bezpieczeństwa narodowego uwzględniającego wszystkie aspekty jego funkcjonowania. Model systemu bezpieczeństwa narodowego nie jest problemem prostym i łatwym do rozwiązania. Na taki stan złożyło się wiele czynników, spośród których wymienić należy te najważniejsze. Po pierwsze stwierdzić należy, że brak jest wystarczająco rozbudowanej jednolitej bazy teoretycznej dotyczącej tego problemu. Część dostępnych materiałów ujmuje problematykę w wąskim bądź bardzo szerokim jej rozumieniu, przy czym co warte podkreślenia, dostarczają one niezwykle cennej wiedzy. Po drugie istnieją różnorodne poglądy związane z problematyką organizacji działań podmiotów państwa na rzecz jego bezpieczeństwa, co wynika z przywiązania do tradycyjnego i utrwalonego selektywnego podejścia, bądź podejścia totalnego. Są to poglądy, które nie wykorzystują w pełni osiągnięć nauki w zakresie dotyczącym organizacji, modelowania i systemów. Budowa modelu systemu bezpieczeństwa narodowego (a w konsekwencji również jego systematyczne doskonalenie) winno być oparte na osiągnięciach nauki. Powinno stanowić jednocześnie wypadkową tych osiągnięć oraz możliwości ich wdrożenia poprzez zastosowanie wartościowych i efektywnych rozwiązań prawnych i organizacyjnych.
\end{abstract}

Słowa kluczowe: bezpieczeństwo, zagrożenia, państwo, administracja, model, system, badania naukowe, wiedza Typ artykułu: artykuł przeglądowy

\footnotetext{
Abstract

Aim: Identification of fundamental attributes for a national security system, which determines the precedence of alternatives for local and business needs.

Introduction: Security of the state, its economic and political development, simultaneous need for the creation of a safe environment, taking account of increasing levels of threats to an open society, compel the practical application of straightforward, scientifically determined solutions. Such an assumption allows for a rational exploitation of national potential. One approach is the creation of a national security system, allowing for simultaneous use of defence elements and crisis management systems.

Methodology: Scientists and people dealing with safety matters share a common opinion with aspirations about the highest level of safety involving efficiency and effective organisation methods in a national security system. The search for such solutions has

${ }^{1}$ Wyższa Szkoła Policji w Szczytnie, ul. Marszałka Józefa Piłsudskiego 111, 12-100 Szczytno, b.wisniewski@wspol.edu.pl / Police Academy in Szczytno, Poland;
} 
continued for many years and solutions are yet to be found. In this vein an analysis was performed about theoretical considerations as well as practical solutions covering national and foreign dimensions.

Results: Security of the state is characterized by dynamic changes attributable to legal and organizational requirements. Such changes create the need to build an efficient national security system, taking into account every aspect of its operation. The national security system is not a simple issue which is easy to address. There are many factors which impact on current circumstances and it is pertinent to highlight the most significant ones. First of all, there is an absence of a single theoretical database concerning this topic. A proportion of accessible information deals with issues in a narrow or very broad manner. However, these materials provide invaluable information. Secondly, there is a proliferation of views concerning the matter of organisational performance involving state entities, within the scope of national security, and are attributable to traditional thinking about selective or total approaches in performance. Such views do not make full use of science in the area concerned with organisations, systems and modelling. The development of a national security system and, subsequently, its systematic improvement, should be based on scientific achievements. Simultaneously, results from scientific achievements should culminate in potential implementation and application of credible, effective, legal and organisational solutions.

Keywords: safety, threats, state, administration, model, system, research, knowledge Type of article: review article

\section{Аннотация}

Цель: Указание основных характеристик модели системы национальной безопасности, определяющих её преимущества над теми системами, которые создаются для местных и отраслевых потребностей.

Введение: Безопасность государства, его экономическое и политическое развитие, и тем самым, участие в формировании безопасной окружающей среды, а также повышение уровня угроз для открытых обществ вызывают необходимость использовать на практике простые научно-обоснованные решения. Такое предположение позволяет более рационально использовать имеющийся потенциал государства. Одним из таких решений является создание системы национальной безопасности, которая позволила бы одновременно использовать защитные элементы и элементы кризисного управления.

Методология: Учёные и специалисты, занимающиеся проблематикой безопасности, согласны, что ради достижения высокого уровня следует искать действенные и эффективные методы организации системы национальной безопасности. Поиск этих решений продолжается в течение многих лет. В поисках используются анализы теоретических рассуждений и практических решений, как национальные, так и зарубежные.

Результаты: Безопасность государства характеризуется динамическими изменениями правовых и концептуальноорганизационных условий. Эти изменения вызывают необходимость создания эффективной системы национальной безопасности, включающей все аспекты ее функционирования. Модель системы национальной безопасности - это не простая и легкая для решения задача. На это повлияло много факторов, среди которых следует отметить наиболее важные. Во-первых, следует сказать, что нет достаточно обширной однородной теоретической базы, касающейся этого вопроса. Часть доступных материалов описывает проблематику в узком или слишком широком значении, при этом стоит подчеркнуть, что эти материалы представляют собой очень ценную информацию. Во-вторых, существуют разные точки зрения, связанные с проблематикой организации действий субъектов государства на благо его безопасности, что возникает с привязанности к традиционному и укреплённому выборочному подходу, или общему подходу.

Эти мнения полностью не используют достижения науки в области организации, моделирования и систем. Создание модели системы национальной безопасности (а в последствии также ее систематическое совершенствование) должно быть основано на достижениях науки. В тоже время должно являться результатом этих достижений и возможности их внедрения благодаря применению качественных и эффективных правовых и организационных решений.

Ключевые слова: безопасность, угрозы, государство, администрация, модель, система, научные исследования, знания Вид статьи: обзорная статья

\section{Wstęp}

Podejście systemowe do problematyki bezpieczeństwa stwarza możliwości mechanizmu porządkującego stan wiedzy o bezpieczeństwie. Kolejną determinantą podejścia systemowego są cechy wszelkich działań podporządkowanych trosce o jego osiągnięcie i utrzymanie bezpieczeństwa, takich jak: antycypacja, adaptacja, celowość działania, skierowanie na rozwój, które są własnościami podejścia systemowego pozostającego nadal nowoczesnym sposobem praktycznego działania. Jego wyróżnikami są [1, s. 94]:

- traktowanie badanego obiektu jako systemu;

- traktowanie danego systemu jako obiektu złożonego z wzajemnie powiązanych podsystemów;

- traktowanie danego systemu jako należącego do większego systemu;
- świadome wykorzystywanie modelu systemu o ściśle określonym poziomie rozdzielności, który to wyraża określony aspekt działania.

Za podejściem systemowym rozważań nad bezpieczeństwem państwa przemawiają jego cechy takie jak:

- holizm, czyli eksploracja zjawisk, obiektów, procesów zdarzeń itd. jako całości;

- kompleksowość, czyli ujawnianie różnorodnych sprzężeń i relacji wewnętrznych;

- esencjalizm, czyli badanie zjawisk (obiektów) z punktu widzenia istotnych cech charakterystycznych;

- strukturalizm, czyli identyfikowanie własności obiektu (obszaru) zainteresowania na podstawie tych cech jego struktury, która uznawana jest za niezmienną i integrującą; 
- kontekstowość, czyli rozpatrywanie systemów ze względu na ich miejsce w większej całości;

- teleologizm, czyli rozpatrywanie zjawisk z punktu widzenia ich celowości w danej dziedzinie, zwłaszcza w całej rzeczywistości;

- funkcjonalność, czyli rozpatrywanie systemów ze względu na osiągane cele oraz wypełniane funkcje;

- efektywność, czyli rozpatrywanie systemów przez pryzmat wielkości rezultatów osiąganych celów i wypełnianych funkcji;

- synergizm, czyli rozpatrywanie właściwości wynikających ze współpracy i współdziałania w ramach systemu podsystemów i elementów tych podsystemów, których istotą jest kooperacja będąca skuteczniejszym działaniem aniżeli suma ich oddzielnych działań;

- rozwój, czyli rozpatrywanie systemów w ujęciu procesu przeobrażeń i zmian związanych z przechodzeniem do stanów lub form bardziej złożonych lub pod pewnym względem doskonalszych.

W przeszłości pojęcia „system” i ,układ”, w odniesieniu do bezpieczeństwa i jego składowych, były używane zamiennie. Uznać to należy za błędne, jak zauważa A. Rogucki z uwagi na wieloznaczność terminu układ w naukach społecznych i prawnych oraz na to, że [2, s. 89]:

- system może znajdować się w różnych stanach, a jego elementy w różnych układach, zatem zakresy znaczeniowe systemu i układu są różne;

- pojęcie „układ” stosowane jest do określania zbiorów, które nie spełniają warunków dynamiki i celowości, jaką przypisuje się systemom rozwijającym się i względnie trwałym.

Przed przystąpieniem do identyfikacji systemu warto zauważyć za J. Zieleniewskim, że przy rozpatrywaniu jakiegoś układu stwierdza się, że jego elementy są pod jakimś względem uporządkowane, więc rozpatrywać go należy pod tym względem jako system [3, s. 41].

W kontekście dotychczasowych rozważań należy przywołać stanowisko L. Kuleszyńskiego, który uznał, że $[4$, s. 44]:

- układ jest zbiorem rzeczy i cech, który z samej definicji nie zmienia swych stanów w czasie oraz nie rozwija działania i nie poddaje się kierowaniu;

- system jest układem dynamicznym, którego elementy mogą zmieniać swe stany w czasie oraz mogą działać i być kierowane.

Ważne jest również to, że w każdym systemie wyróżnia się podsystem kierowania oraz podsystem wykonawczy.

W związku z tym, że system bezpieczeństwa narodowego funkcjonuje w pewnym środowisku (otoczeniu), środowisko to (otoczenie) oddziałuje na niego zwrotnie. Jest więc ono ,zbiorem elementów zewnętrznych w stosunku do systemu i pozostających $\mathrm{w}$ interakcji $\mathrm{z}$ systemem. Każdy system ma swój nadsystem, a więc jest w strukturze systemowej określona hierarchia" [5, s. 204205]. System bezpieczeństwa można postrzegać przez pryzmat działania. Będzie on zatem systemem społecz- nym (kompleksem systemów), który wraz z niezbędnymi sposobami i środkami działania wytycza, a następnie dąży do osiągnięcia określonych celów [6, s. 263].

Przedstawione do tej pory rozważania zdecydowały o tym, aby w tej części opracowania przedstawić zasadnicze problemy dotyczące założeń opisu systemu bezpieczeństwa narodowego, aby w oparciu o nie dokonać charakterystyki i przedstawić organizacyjne aspekty tegoż systemu.

\section{Analiza pojęciowa}

Pojęcie ,system” pochodzi od greckiego słowa systematiós, co oznacza ,zestawiony” [7, s. 492].

W powszechnym odbiorze system oznacza:

- ,zestawienie, całościowy i uporządkowany układ, zbiór przedmiotów, zasad i twierdzeń, reguł postępowania" [7, s. 492];

- „skoordynowany układ elementów, zbiór tworzący pewną całość uwarunkowaną stałym, logicznym uporządkowaniem jego całości” [8, s. 387];

- „całościowy i uporządkowany zespół zadań połączonych ze sobą stosunkami logicznego wynikania" $[9$, s. 1065].

Podobnie wyżej wymieniony termin określany jest w Słowniku języka polskiego [10, s. 289] A. Arnolda, w którym wyjaśniany jest m.in. jako:

- ustalony porządek wykonywania czegoś, zasady funkcjonowania;

- zbiór twierdzeń tworzących jakąś teorię.

Zgodnie z Encyklopedia organizacji i zarządzania termin ,system” należy rozumieć jako wyodrębniony z otoczenia zbiór elementów materialnych lub abstrakcyjnych mających wzajemne powiązania wewnętrzne i rozważanych jako całość. Nie sposób pominąć wyjaśnienia znaczenia wyżej wymienionego pojęcia, zawartego w opracowaniu Zarządzanie, teoria i praktyka, którego autorzy postrzegają system jako zestaw składników, między którymi zachodzą wzajemne stosunki (interakcje), i gdzie każdy składnik połączony jest z każdym innym bezpośrednio lub pośrednio [11, s. 761]. Równie interesująca wydaje się definicja systemu zawarta w Nowej encyklopedii powszechnej $P W N$, która określa system jako zbiór wzajemnie powiązanych elementów, wyodrębnionych $\mathrm{z}$ otoczenia ze względu na te powiązania, przy czym powiązania (relacje) między elementami systemu tworzą jego strukturę, oraz jako zespół sposobów (metod) działania, wykonywania złożonych czynności, a także całokształt zasad organizacji, ogół norm i reguł obowiązujących w danej dziedzinie [12, s. 152]. Równie interesujących informacji dostarcza Leksykon wiedzy wojskowej prezentujący wieloaspektowe spojrzenie na pojęcie systemu, które definiowane jest tam następująco [13, s. 426]:

- wszelki skoordynowany wewnętrznie i wykazujący określoną strukturę układ elementów;

- zespół sposobów (metod) działania, wykonywania złożonych czynności;

- całokształt zasad organizacyjnych, ogół norm i reguł obowiązujących w danej dziedzinie; 
- całościowy i uporządkowany zespół zadań powiązanych ze sobą określonymi stosunkami logicznymi.

Wyżej zaprezentowane określenia pojęcia system charakteryzują się syntetycznym oddaniem istoty tego terminu.

Nieco więcej informacji do opisu systemu znaleźć można w opracowaniach teoretyków. I tak, pod pojęciem system P. Sienkiewicz rozumie określone zjawisko w naturze i społeczeństwie składające się z poszczególnych elementów, między którymi zachodzą określone relacje. System ma więc strukturę, a w aspekcie cybernetycznym charakteryzuje go dynamika i spełnienie określonej funkcji [14, s. 35]. Natomiast J. Habr, J. Veprek określają system jako ,celowo określony zbiór elementów i zbiór sprzężeń między nimi, które wspólnie określają właściwości całości” [15, s. 32]. Podobną definicję do powyższej proponuje R. Kulikowski, który uważa, że system to „zespół elementów lub obiektów, które są zespolone lub powiązane w całości przez określone związki” [16, s. 9]. Z kolei W. Kieżun określa system jako wyodrębnioną całość otaczającej nas rzeczywistości, mającą wyodrębnioną strukturę, a więc składającą się $\mathrm{z}$ części uporządkowanych według ustalonych reguł, określających ich wzajemne relacje [17, s. 13].

Analiza przytoczonych powyżej definicji uprawnia do stwierdzenia, że system spełnia następujące warunki:

- posiada własną strukturę złożoną z pojedynczych jednostek oraz powiązań między nimi;

- jest wyodrębniony z większej całości i posiada granice tej odrębności;

- posiada zespół reguł określających jego funkcjonowanie.

W kontekście przytoczonych powyżej rozważań należy przyjąć za P. Sienkiewiczem, że system to każdy złożony obiekt, wyróżniony $\mathrm{z}$ badanej rzeczywistości, przedstawiany jako pewna całość i tworzony przez zbiór obiektów elementarnych (elementów) i powiązań (relacji) pomiędzy nimi [18, s. 82].

Charakterystyka systemu bezpieczeństwa nie byłaby możliwa bez krótkiej chociażby charakterystyki systemów. Kryteriów typologicznych systemów jest wiele. Ograniczenia niniejszej pracy pozwalają jednak na prezentację tych, które $\mathrm{z}$ racji przedmiotu i podmiotu rozważań uznano za najbardziej przydatne.

Wydaje się, że podstawowym kryterium typologicznym jest wielkość systemu. P. Sienkiewicz dokonuje podziału systemu pod tym względem na trzy klasy wielkości [19, s. 47]:

- proste - składające się z obiektów elementarnych, wśród których żaden nie może być uznany za system;

- złożone - składające się z obiektów, wśród których co najmniej kilka można traktować jako systemy proste;

- wielkie - składające się z obiektów określanych przynajmniej jako systemy proste.

W podobnym duchu, lecz biorąc pod uwagę inny aspekt, wypowiada się W. Mróz, proponujący podział wg tych samych kryteriów na systemy [20, s. 110]:
- proste, charakteryzujące się tym, że występuje w nich mała liczba wewnętrznych powiązań i nie sprawiają trudności w opisie matematycznym;

- złożone, charakteryzujące się tym, że dają się opisać matematycznie, ale już z dużymi trudnościami z powodu rozgałęzionej struktury i większej liczby wewnętrznych powiązań;

- bardzo złożone, charakteryzujące się tym, że nie poddają się opisowi matematycznemu z powodu bardzo dużego rozgałęzienia i skomplikowanej struktury wewnętrznej.

Systemy można także podzielić ze względu na wymienialność elementów systemów, w trakcie ich działania. Systemy te dzieli się na: otwarte, domknięte oraz zamknięte.

Z kolei w ujęciu przedmiotowym i podmiotowym systemy można podzielić na: rzeczywiste (reprezentujące określoną rzeczywistość) i pojęciowe (będące pewnymi konstrukcjami myślowymi). Te pierwsze z kolei można podzielić na homogenne (jednorodne w sensie cech gatunkowych) oraz heterogenne (zespalające cechy systemowe poszczególnych klas systemów homogennych) [21, s. 10].

Jednym ze sposobów podejścia systemowego jest modelowanie, które w kontekście bezpieczeństwa państwa będzie służyć skonstruowaniu obrazu stanowiącego swoisty wzorzec. Modelowanie jest bowiem procesem konstruowania obrazu danego fragmentu rzeczywistości, zwanego oryginałem, wyrażonym w przyjętym języku (kodzie) za pomocą określonej metody badawczej i zgodnie z wiedzą przedmiotu [22, s. 76]. Natomiast modelowanie systemowe oznacza „całokształt przedsięwzięć poznawczych, związanych z tworzeniem modeli i obiektów, których znajomość cech skłania do traktowania go jako systemu" [1, s. 4]. Uwzględniając doświadczenie badacza, jego intuicję, wiedzę na temat przedmiotu badań, można wyodrębnić trzy orientacje modelowe takie jak [22, s. 108-109]:

- orientacja modelowa, której istota polega na preferowaniu kryteriów poprawności logicznej modelu w wymiarze wewnętrznym, co może odbyć się kosztem adekwatności;

- orientacja przedmiotowa, której istota polega na preferowaniu wskaźników zgodności modelu z arbitralnie wybranym fragmentem rzeczywistości, co może się odbyć kosztem poprawności logicznej modelu;

- orientacja podmiotowa, której istota polega na adaptacji zadania do możliwości i kwalifikacji podmiotu.

Dla stworzenia podstaw do pełnego przedstawienia założeń opisu systemu bezpieczeństwa narodowego niezbędne wydaje się wyjaśnienie pojęcia „,model”, które rozumiane jest jako:

- „sformalizowane wyrażenie teorii lub związku, który traktujemy jako uogólnienie" [23, s. 184-187];

- konkretny interpretacyjny wyraz teorii albo jednej lub kilku hipotez [24, s. 111];

- „uproszczone odwzorowanie, często połączone z pewną schematyzacją lub stylizacją" [25, s. 51]. 
Po zaprezentowaniu zasadniczych problemów dotyczących istoty modelowania oraz modelu należy przedstawić typologię modeli stosowanych w badaniach systemowych. Według P. Sienkiewicza modele można podzielić ze względu na [26, s. 91]:

- cel poznawczy (rezultat modelowania);

- formę przekazu (język modelowania);

- aspekt badań systemowych.

I tak, podział modeli ze względu na cel poznawczy obejmuje modele [26, s. 91]:

- ocenowe, których istota jest uzyskanie ocen będących wyrazem aprobaty bądź negacji dla stanu systemu;

- decyzyjne, których istotą jest uzyskanie ściśle określonych decyzji koniecznych do zapewnienia pożądanego stanu systemu z uwagi na przyjęte kryteria;

- desygnujące, których istotą jest pełne wyjaśnienie cech systemu.

Natomiast podział ze względu na formę przekazu obejmuje modele [26, s. 91]:

- opisowe, czyli wyrażane w języku naturalnym;

- formalne, czyli wyrażane w języku logiki;

- matematyczne, czyli wyrażane w języku matematyki.

Podział modeli ze względu na przyjmowany aspekt badań pozwala na wyróżnienie trzech zasadniczych postaci systemu, a mianowicie: morfologii, funkcjonowania i rozwoju. [26, s. 91]

Uwzględniając powyżej zaprezentowane rozważania oraz kwestie oparcia wszelkich założeń systemu bezpieczeństwa narodowego o przepisy prawa, należy stwierdzić, że postanowienia prawa regulujące funkcjonowanie systemu bezpieczeństwa narodowego nie pozwalają na jednoznaczną teoretyczną identyfikację tego pojęcia. Analiza tychże dokumentów pozwala jednak wyodrębnić wspólne cechy elementów systemu bezpieczeństwa narodowego łączące je w jedną całość $\mathrm{z}$ punktu widzenia właściwości organizacyjno-rzeczowych. Taki stan rzeczy, uwzględniając treści poprzedniego podrozdziału, pozwala rozpatrywać elementy systemu bezpieczeństwa narodowego w czterech ujęciach tj. w ujęciu podmiotowym, przedmiotowym, strukturalnym oraz formalnym.

$\mathrm{W}$ ujęciu podmiotowym elementy systemu bezpieczeństwa narodowego stanowią ogół podmiotów wykonujących określone funkcje (obowiązki) związane z zapewnieniem warunków bezpiecznego funkcjonowania struktur państwa oraz ochroną ludności i majątku narodowego przed skutkami oddziaływań kryzysowych i wojennych. Natomiast w ujęciu strukturalnym rozpatrywać je należy jako podmioty realizujące wyżej wymienione funkcje na wszystkich szczeblach organizacyjnych państwa. Wskazane powyżej założenie pozwoliło także ustalić, iż istotą ujęcia przedmiotowego jest działalność, której przedmiotem jest chronione dobro. Rozpatrywanie całokształtu działalności prowadzonej przez elementy systemu bezpieczeństwa narodowego, bez względu na to czy ma ona charakter przedmiotowy czy nie, było rozpatrywaniem tej problematyki w ujęciu formalnym. Takie ujęcie pozwala na kompleksowe podejście do problemu funkcjonowania systemu bezpieczeństwa narodowego.

Uwzględniając zaprezentowane na wstępie warunki, jakim winien odpowiadać system oraz kompetencji organów władzy i administracji publicznej, można stwierdzić, że elementy systemu bezpieczeństwa narodowego w aspekcie prawnym:

- stanowią wyodrębnioną całość;

- posiadają określoną właściwość;

- działają w imieniu państwa;

- działają w zakresie przyznanych im kompetencji.

Wyodrębnienie polega na tym, że posiadają określoną przez prawo strukturę organizacyjną zapewniającą ich jednolitość. Wyodrębnienie, o którym mowa, dotyczy zarówno szczebla centralnego, jak i terenowego (województwa, powiatu itp.).

Właściwość udziela odpowiedzi na pytanie, jaki element jest powołany do realizacji przedsięwzięć wchodzących w obszar spraw danego rodzaju. „Dokładne określenie właściwości (...) jest konieczne (...), gdyż zapobiega to sporom kompetencyjnym i zbędnym działaniom" [27, s. 217].

Działanie w imieniu państwa należy rozumieć tak, że za efekty ich działania odpowiedzialność ponosi państwo, jako centralna i najpotężniejsza instytucja władztwa publicznego [28, s. 35-36].

Istotą działania elementów systemu bezpieczeństwa narodowego w zakresie ich kompetencji jest ich funkcjonowanie $\mathrm{w}$ ramach przyznanego im przez przepisy prawa określonego zakresu działania, zadań i obowiązków, pozwalających odróżnić je od innych systemów.

O kształcie systemu bezpieczeństwa narodowego decydują relacje: normatywne, informacyjne, współdziałania oraz materialne.

Relacje normatywne w postaci „Konstytucji Rzeczypospolitej Polskiej, ratyfikowanych umów międzynarodowych oraz ustaw uchwalanych przez Parlament (władzę ustawodawczą). W przypadku, gdy zapisy ustawowe w sferze bezpieczeństwa (zwłaszcza dotyczące kompetencji organów administracji publicznej) budzą kontrowersje, interpretacji poszczególnych zapisów dokonuje Trybunał Konstytucyjny (władza sądownicza). Na podstawie delegacji ustawowych Rada Ministrów lub właściwi ministrowie (...) wydają rozporządzenia, które obrazują relacje normatywne wykonawcze, dotyczące podsystemów wykonawczych systemu bezpieczeństwa narodowego. Relacje informacyjne przebiegają od otoczenia (informacje o sytuacji zewnętrznej) do wewnątrz systemu, a także od podsystemów wykonawczych (w postaci informacji o działaniach $\mathrm{w}$ podsystemach militarnym i niemilitarnym) do podsystemu kierowania (...)" [29, s. 33-34]. Relacje współdziałania ogólne zachodzą pomiędzy podsystemami wykonawczymi, jak również pomiędzy nimi a otoczeniem systemu bezpieczeństwa narodowego.

Wyróżnia się trzy typy relacji materialnych: finansowe, usługowe oraz usługowe i produkcyjne. Relacje finansowe charakteryzują budżetowanie wydatków przeznaczanych na zapewnienie bezpieczeństwa i przebiegają od decydenta (Parlament) do elementów systemu bez- 
pieczeństwa narodowego. Relacje usługowe przebiegają od podsystemów wykonawczych do podsystemu kierowania. Relacje usługowe i produkcyjne dotyczą zaspokojenia potrzeb wszystkich elementów systemu bezpieczeństwa narodowego w zakresie wyrobów oraz usług materialnych i niematerialnych [29, s. 34].

Zanim zostanie przedstawiona konkluzja odnoszaca się do dociekań przedstawionych w niniejszym podrozdziale, należy zauważyć, że nie istnieje taki opis „obiektu empirycznego jako systemu, który uwzględniałby możliwe wyniki badań systemowych, wyrażone celem poznawczym (lub praktycznym) teorii systemów. Powyższą tezę można sformułować $\mathrm{w}$ postaci zasady relatywności systemów, przez którą rozumiemy konieczność przyjmowania w opisie obiektu jako systemu określonego aspektu badań systemowych" [30, s. 17]. W ścisłym związku z powyższą zasadą pozostaje również zasada nieokreśloności systemów G. Weinberga, który stoi na stanowisku, że „W opisie obiektów złożonych nie jesteśmy w stanie uzyskać pewności, czy zaobserwowane ograniczenie swobody przypisać systemowi, czy też jego otoczeniu" [31, s. 47].

Reasumując, należy zauważyć, że z uwagi na charakter państwa jako organizacji oraz bezpieczeństwa narodowego wydaje się, że w badaniach systemowych modelu systemu bezpieczeństwa narodowego należy zastosować podejście morfologiczno-funkcjonalno-rozwojowe.

Uwzględniając dotychczasowe rozważania, należy stwierdzić, że system bezpieczeństwa narodowego jest wielkim systemem rzeczywistym:

- w ujęciu wąskim: składającym się z systemu działalności bieżącej, systemu zarządzania kryzysowego oraz systemu obronnego na co wskazują wieloletnie badania prowadzone przez autora (którym dał wyraz w swym opracowaniu pt. „System bezpieczeństwa państwa. Konteksty teoretyczne i praktyczne", Szczytno 2013);

- w ujęciu szerokim: stanowiącym ogół podmiotów prowadzących działalność na wszystkich szczeblach organizacyjnych państwa i relacji zachodzących między nimi, związaną z zapewnieniem warunków do bezpiecznego funkcjonowania państwa w sytuacjach kryzysowych, w warunkach niezagrożenia, zagrożeń niemilitarnych (pozamilitarnych) i militarnych oraz wojny.

Analiza rozwiązań prawno-organizacyjnych wskazuje na to, że system bezpieczeństwa narodowego opiera się na powszechnie obowiązującym prawie, wymagającym systematycznego doskonalenia zarówno w zakresie aktualności, jak i rozległości regulacji.

Rozległość takiej płaszczyzny działalności państwa jak zapewnienie bezpieczeństwa pozwala na dostrzeganie ścisłych związków między działalnością bieżącą a przygotowaniami obronnymi i zarządzaniem kryzysowym, bowiem są one niczym więcej, aniżeli procesem ,rozwiązywania napiętych sytuacji w sposób, w którym szereg współzależnych operacji jest planowany, organizowany, kierowany i kontrolowany. Wytyczany jest także kierunek procesu decyzyjnego dla osób odpowiedzialnych za podejmowanie decyzji w celu uzyskania szybkiego, lecz nie pochopnego rozwiązania problemu, w obliczu którego znalazła się organizacja" [32, s. 150].

Zarówno teoria, jak i praktyka działalności w zakresie bezpieczeństwa dowodzi niezbicie, że podmiotem tego zarządzania jest człowiek, a jego przedmiotem - bezpieczeństwo. Związane jest to bezpośrednio $z$ kierowaniem zespołami ludzkimi w szczególnych, trudnych i złożonych warunkach. Pozostaje to z kolei w ścisłym związku ze świadomością znaczenia kierowania na wszystkich poziomach kierowania organizacjami.

\section{Wnioski}

Procedury postępowania w warunkach zagrożeń, kryzysu, sytuacji kryzysowych oraz przewidywanych do realizacji w warunkach zewnętrznego zagrożenia bezpieczeństwa państwa i wojny są w pewnym zakresie jednolite dla wszystkich elementów systemu bezpieczeństwa narodowego, każdej z możliwych do badania organizacji oraz jednocześnie odmienne w zakresie wynikającym z właściwości tych elementów. Taka teza wymusza wprowadzenie optymalnych rozwiązań we wszystkich przywołanych zakresach, które w konsekwencji ma doprowadzić do doskonalenia podstaw prawnych i organizacyjnych, a w skali mikro również wprawy w realizacji zadań w sytuacjach kryzysowych. Nie ulega przecież wątpliwości, że „człowiek wykonujący jakąkolwiek nową czynność spełnia ją na ogół dużo wolniej i przy większym nakładzie energii niż człowiek, który tę czynność wielokrotnie powtarzał" [33, s. 7]. Najprostszym sposobem osiągnięcia wyżej wymienionych celów jest podejście systemowe, które pozwala w odniesieniu do systemu bezpieczeństwa narodowego dostrzec: ścisłe określenie granic i wnętrza systemu, niezmienność dokonanego rozróżnienia między systemem a jego otoczeniem, zupełność podziału wewnętrznego systemu na podsystemy oraz rozłączność rozpatrywanych jego części [34, s. 65]. System bezpieczeństwa narodowego może być uznany za system wielki, ponieważ:

- jest on nadsystemem dla systemów, które wchodzą w jego skład;

- w jego skład wchodzą systemy: działalności bieżącej w obszarze bezpieczeństwa, zarządzania kryzysowego i obronny;

- systemy, o których mowa powyżej, mają swoje podsystemy (kierowania i wykonawcze);

- przywołane podsystemy posiadają swoje elementy.

System ten powinien być w założeniach:

- sprawny, co oznacza, że powinien wykorzystywać zasoby państwa w sposób racjonalny bez zbędnego marnotrawstwa oraz w odpowiednim czasie;

- skuteczny, co sprowadza się do realizacji takich przedsięwzięć, które gwarantują pełne bezpieczeństwo państwa i wszystkich jego komponentów. 


\section{Literatura}

1. Sienkiewicz P., Urbanek M., Kinasiewicz M., Zastosowanie modeli analizy sytuacji polityczno-militarnej $i$ społeczno-ekonomicznej do oceny potencjałów bojowych i struktur organizacyjnych Sił Zbrojnych RP [w:] Doskonalenie, Program naukowy AON, Warszawa 1992.

2. Rogucki A., Analiza systemów w planowaniu obrony. Aspekty ekonomiczno-polityczne, Wyd. MON, Warszawa 1975.

3. Zieleniewski J., Organizacja zespołów ludzkich, PWN, Warszawa 1964.

4. Kuleszyński L., Dowodzenie wojskami a cybernetyka, Wyd. MON, Warszawa 1967.

5. Kieżun W., Podstawy organizacji $i$ zarządzania, Książka i wiedza, Warszawa 1975.

6. Sienkiewicz P., Teoria efektywności systemów kierowania, Tom I - wstę do systemologii, Wyd. ASG WP, Warszawa 1979.

7. Kopaliński W., Słownik wyrazów obcych i zwrotów obcojęzycznych z almanachem, Wiedza Powszechna, Warszawa 1994.

8. Szymczak M. (red. nauk.), Słownik języka polskiego, tom III, PWN, Warszawa 1981.

9. Sobol E. (red. nauk.), Słownik wyrazów obcych, PWN, Warszawa 1995.

10. Arnold A., Słownik języka polskiego, Wydawnictwo szkolne PWN, Warszawa 2011.

11. Koźmiński A.K., Piotrowski W., Zarządzanie, teoria i praktyka, PWN, Warszawa 2000.

12. Nowa encyklopedia powszechna, PWN, Warszawa 1995.

13. Leksykon wiedzy wojskowej, MON, Warszawa 1979.

14. Sienkiewicz P., Inżynieria systemów, MON, Warszawa 1983.

15. Habr J., Veprek J., Systemowa analiza i synteza, PWE, Warszawa 1976.

16. Kulikowski R., Sterowanie $w$ wielkich systemach, WNT, Warszawa 1970.

17. Kieżun W., Sprawne zarządzanie organizacją, Szkoła Główna Handlowa, Warszawa 1997.

18. Sienkiewicz P., Podstawy teorii systemów, Wyd. AON, Warszawa 1993.

19. Mróz W., Kierowanie i organizacja pracy sztabowej w okresie pokoju, Wyd. MON, Warszawa 1993.

20. Górski P., Zastosowanie modelowania systemowego do opisu wybranych elementów systemu obronnego państwa, Wyd. AON, Warszawa 1998.

21. Sienkiewicz P., Systemy kierowania, Wiedza Powszechna, Warszawa 1974.

22. Krzyżanowski L., Podstawy nauk o organizacji i zarządzaniu, PWN, Warszawa 1994.
23. Barton R.F., Wprowadzenie do symulacji gier, PWN, Warszawa 1989.

24. Bojarski W.W., Podstawy analizy i inżynierii systemów, Warszawa 1984.

25. Sienkiewicz P., Inżynieria systemów kierowania, Warszawa 1988.

26. Ochendowski E., Prawo administracyjne, Dom Organizatora, Toruń 1999.

27. Stawecki T., Winczorek P., Wstęp do prawodawstwa, Wyd. C.H. Beck, Warszawa 1999

28. Górski P., Aspekty niemilitarne systemu obronnego państwa [w:] Współdziałanie struktur organizacyjnych resortu spraw wewnętrznych $i$ administracji z pozostatymi elementami systemu obronnego, Kulczycki R. Wiśniewski B. (red.), MSWiA, Warszawa 2005.

29. Weinberg G., Myślenie systemowe, Wydawnictwa Naukowe i Techniczne, Warszawa 1979.

30. Armstrong M., Jak być lepszym menedżerem, Dom Wydawniczy ABC, Warszawa 1997.

31. Frąckiewicz J., Organizacja pracy i kierowania, PWE, Warszawa 1969.

32. Sienkiewicz P., Analiza systemowa. Podstawy i zastosowania, Wyd. Bellona, Warszawa 1994.

33. Penc J., Nowe perspektywy zarzadzania. Ku etycznemu paradygmatowi zachowań w organizacji, [w:] Etyka w zarzadzaniu Policja, Letkiewicz A. (red.), Wyd. WSPOL, Szczytno 2011.

34. Wiśniewski B., System bezpieczeństwa państwa. Konteksty teoretyczne i praktyczne, Wyd. WSPOL, Szczytno 2013.

dr hab. Bernard Wiśniewski - profesor nadzwyczajny Wyższej Szkoły Policji w Szczytnie oraz Szkoły Głównej Służby Pożarniczej w Warszawie. Dyrektor Regionalnego Centrum Badań nad Bezpieczeństwem w Bielsku-Białej. Członek Rady Naukowej Centrum Badań nad Terroryzmem Collegium Civitas oraz „Rocznika bezpieczeństwa morskiego” wydawanego przez Akademię Marynarki Wojennej w Gdyni. Autor ponad dwustu opracowań naukowych i popularno-naukowych opublikowanych w Polsce oraz w Niemczech, Czechach, Słowacji, Wielkiej Brytanii, Litwie i Stanach Zjednoczonych. Specjalizuje się w problematyce bezpieczeństwa narodowego, bezpieczeństwa wewnętrznego państwa, zarządzania kryzysowego, przygotowań obronnych administracji publicznej oraz edukacji dla bezpieczeństwa. 